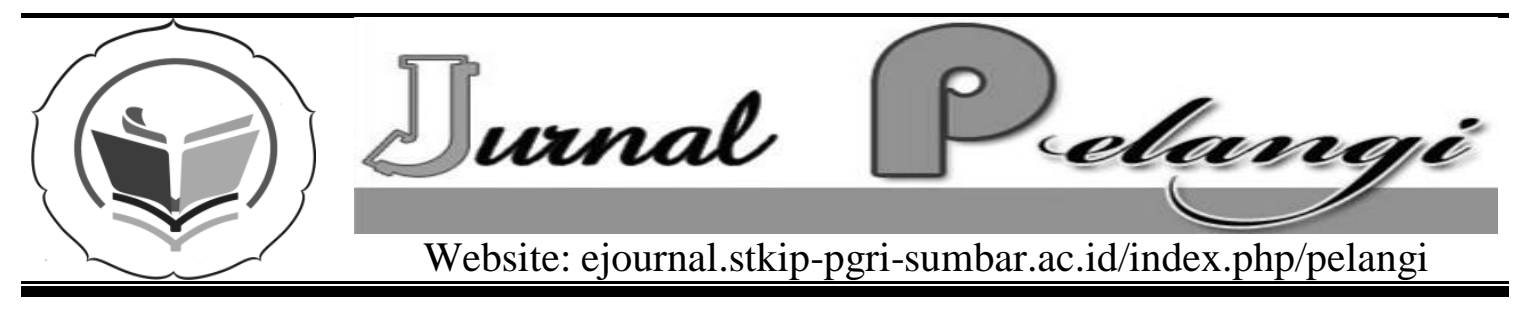

\title{
PENERAPAN STRATEGI SEPAK BOLA VERBAL DISERTAI LKS PADA PEMBELAJARAN BIOLOGI SISWA KELAS VIII MTsN PADANG SIBUSUK KABUPATEN SIJUNJUNG Siska Nerita \\ STKIP PGRI Sumatera Barat
}

\section{INFO ARTIKEL}

\section{Diterima:}

Direview:

Disetujui:

Keyword:

Applying verbal football strategy, Studenst work sheet, Learning outcome

\section{PENDAHULUAN}

Guru adalah sumber yang menempati posisi dan memegang peranan penting dalam pendidikan. Sebagai tenaga

\section{Abstrak}

This research has background of problem is low of students learning outcome in Biologi Learning at MTSN Padang Sibusuk Kabupaten Sijunjung. It is caused by some factors, such as passive students in learning, they didn't have cooperation, and they often saw the book or asked to their friend when the test done. Based on those problems, so the research would apply a strategy that called verbal football. This research has purpose to know whether using verbal football strategy can improve students learning outcome in learning Biologi. Kinds of this research is experimental research with research design is random control grouponly desigh. Population of this research are all of students at eight grade MTSN Padang Sibusuk Sijunjung. Technich of gathering sampling is purposive sampling, as experimental class is VIII2 and VIIII as control class. The instrumentasi is final test of learning outcome and the data analysis is done by using T-test. Base on analysis, taken means score of experimental class is 70,90, even though, control class is 60,18. From T-test analysis is taken tmt $(2,88)>$ ttable $(1,68)$. So it can be concluded that verbal football strategy by using students work sheet can improve learning outcome of Biology subject students of at eight grade of MTSN Padang Sibusuk Kabupaten Sijunjung. pendidik, guru merupakan salah satu faktor penentu keberhasilan setiap upaya pendidikan. Untuk meningkatkan hasil belajar siswa, seorang guru harus 
mampu menyelenggarakan proses pembelajaran dengan baik. Upaya yang dapat dilakukan guru untuk meningkatkan pemahaman siswa terhadap pembelajaran yang diberikan adalah dengan menggunakan berbagai macam strategi dan model pembelajaran, diharapkan proses belajar menjadi lebih bermakna dan menyenangkan sehingga siswa akan lebih aktif serta hasil yang diperoleh akan lebih baik. Selain model pembelajaran yang tepat digunakan dalam proses pembelajaran, suasana kelas yang baik juga sangat mendukung motivasi siswa untuk belajar.

Salah satu cara yang dapat digunakan untuk membangkitkan minat belajar siswa adalah dengan menerapkan permainan dalam proses pembelajaran. Hal ini sesuai dengan pendapat Ginnis (2008:214) bahwa Permainan adalah latihan yang menyenangkan untuk memancing pendapat atau keterampilan siswa, dan bisa dijadikan landasan yang dapat mendorong siswa untuk berpatisipasi dalam pembelajaran. Berdasarkan pengamatan penulis di MTsN Padang Sibusuk Kabupaten Sijunjung, pembelajaran yang dilakukan di kelas VIII masih terpusat pada guru. Guru menerangkan materi di depan kelas, siswa hanya mencatat, mengerjakan latihan dan diakhir pembelajaran diberikan pekerjaan rumah.

Siswa cenderung pasif, malu bertanya dan kurang berpartisipasi dalam pembelajaran. Interaksi siswa dengan siswa lainnya dalam pembelajara sangat rendah. Hal ini mengakibatkan situasi belajar monoton, siswa cepat bosan dan kurang serius dalam belajar. Informasi yang penulis peroleh dari wawancara dengan guru biologi MTsN Padang Sibusuk, mengemukakan faktor penyebab rendahnya hasil belajar siswa di antaranya, kurangnya minat dan motivasi siswa untuk belajar biologi.Berbagai usaha telah dilakukan oleh guru untuk meningkatkan hasil belajar siswa, seperti menempelkan hasil nilai ujian siswa di dinding mulai dari nilai tertinggi sampai terendah. Gunanya untuk memotivasi siswa agar lebih giat lagi belajar, namun masih banyak siswa yang tidak peduli. Kondisi di atas sangat mempengaruhi hasil belajar biologi siswa dalam proses pembelajaran. Pada tabel di bawah ini dapat dilihat hasil belajar siswa kelas VIII MTsN Padang Sibusuk Kabupaten Sijunjung.

Tabel 1. Rata-rata Nilai Ulangan Harian Biologi Semester I Siswa Kelas VIII MTsN Padang Sibusuk Kabupaten Sijunjung Tahun Pelajaran 2010/2011.

\begin{tabular}{|c|c|c|c|c|}
\hline \multirow{2}{*}{ Kelas } & \multirow{2}{*}{ Nilai Rata-rata } & \multirow{2}{*}{$\begin{array}{c}\text { Jumlah Siswa } \\
\text { Keseluruhan }\end{array}$} & \multicolumn{2}{|c|}{ Jumlah Siswa } \\
\cline { 3 - 5 } & & 19 & Tuntas & Tidak Tuntas \\
\hline VIII $_{1}$ & 51,57 & 19 & 7 & 10 \\
\hline VIII $_{2}$ & 48,94 & 20 & 9 & 11 \\
\hline VIII $_{3}$ & 50,95 & & \\
\hline
\end{tabular}

Berdasarkan Tabel 1 di atas, secara keseluruhan rata-rata nilai ulangan harian biologi kelas VIII pada waktu semester I di MTsN Padang Sibusuk masih rendah. Jika hal ini dibiarkan berlanjut maka siswa akan sulit untuk memahami materi untuk tingkat yang lebih tinggi karena dalam biologi antara materi yang satu dengan yang lainnya saling berkaitan. Untuk mengatasi masalah tersebut, perlu 
dilakukan variasi metode dan strategi dalam pembelajaran biologi. Salah satu strategi yang dapat diterapkan oleh guru untuk meningkatkan hasil belajarnya adalah strategi Sepak Bola Verbal. Strategi ini belum pernah diterapkan di MTsN Padang Sibusuk Kabupaten Sijunjung. Strategi Sepak Bola Verbal ini dapat digabungkan dengan

LKS (Lembar Kerja Siswa). Dengan adanya LKS siswa dapat menguji pemahamannya terhadap materi yang diberikan dalam bentuk latihan-latihan yang harus dikerjakan. LKS ini dapat menyatukan pendapat siswa dalam menjawab pertanyaan yang diberikan, karena dalam strategi Sepak Bola Verbal dibutuhkan kerja kelompok tiap tim. Berdasarkan uraian di atas, maka dilakukan penelitian dengan judul Penerapan Strategi Sepak Bola Verbal Disertai LKS Pada Pembelajaran Biologi Siswa Kelas VIII MTsN Padang Sibusuk Kabupaten Sijunjung Tahun Pelajaran 2011/2012.

Batasan Masalah

Agar terpusatnya penelitian ini maka penulis membatasinya dengan menggunakan strategi Sepak Bola Verbal yang disertai LKS pada materi Pertumbuhan dan Perkembangan terhadap hasil belajar siswa kelas VIII MTsN Padang Sibusuk Kabupaten Sijunjung yang dinilai dari ranah kognitif.

Rumusan Masalah

Rumusan masalah penelitian
adalah Bagaimanakah hasil belajar
biologi siswa kelas VIII MTsN Padang
Sibusuk Kabupaten Sijunjung dengan

menggunakan strategi Sepak Bola Verbal yang disertai LKS?

Tujuan Penelitian

Tujuan dari penelitian ini adalah untuk mengetahui apakah dengan menggunakan Strategi Sepak Bola Verbal disertai LKS dapat meningkatkan hasil belajar biologi siswa kelas VIII MTsN Padang Sibusuk Kabupaten Sijunjung Tahun Pelajaran 2011/2012 dan dapat meningkatkan pemahaman siswa mengenai materi yang diajarkan.

Kegunaan Penelitian

Kegunaan penelitian ini adalah sebagai berikut :

1. Pengalaman bagi peneliti dalam mempersiapkan diri sebagai calon guru biologi.

2. Bahan masukan bagi guru biologi di MTsN Padang Sibusuk Kabupaten Sijunjung dalam memilih strategi pembelajaran yang akan digunakan dalam pembelajaran biologi.

\section{KERANGKA TEORITS}

\section{Strategi Belajar Aktif}

Belajar aktif sebagai suatu strategi dalam pengelolaan sistem pembelajaran melalui cara-cara yang menuntut keterlibatan siswa secara aktif sehingga tercipta belajar mandiri. Dalam belajar aktif, siswa dan guru bersamasama menciptakan suatu pengalaman belajar yang bermakna sehingga siswa dapat beraktivitas selama proses pembelajaran berlangsung dan melakukan sesuatu dengan aktif baik secara fisik maupun mental. Belajar aktif menuntut siswa untuk bersemangat, 
menyenangkan dan penuh gairah sehingga siswa merasa leluasa dalam berfikir dan beraktivitas. Suryabrata (2004:71) manyatakan bahwa keaktifan siswa dapat dilihat dari :

a. Berbuat sesuatu untuk memahami materi pelajaran dengan penuh keyakinan.

b. Mempelajari, mengalami dan menemukan sendiri bagaimana memperoleh situasi pengetahuan.

c. Merasakan sendiri bagaimana tugastugas guru yang diberikan kepadanya.

d. Belajar dalam kelompok.

e. Mencobakan sendiri konsep-konsep tertentu.

f. Mengkomunikasikan hasil pikiran, penemuan dan penghayatan nilai-nilai secara lisan.

\section{Strategi Sepak Bola Verbal}

Dalam Trik dan Taktik Mengajar (Ginnis:2008) terdapat berbagai macam strategi untuk pencapaian pengajaran di kelas. Strategi itu di antaranya adalah Kartu Panggilan, Bingo, Komidi Putar Diskusi, Domino, Kursi Panas, One-toOne, Quick on The Draw, Sepak Bola Verbal, Roda Keberuntungan, Berburu Informasi, Berwisata, Papan Memori, dan lain-lain. Dari sekian banyak strategi yang ada, penulis tertarik menggunakan strategi Sepak Bola Verbal karena dapat melatih siswa berbicara di depan kelas, dan belajar untuk menyampaikan pendapat dalam diskusi.

Menurut Ginnis (2008:186)

Strategi Sepak Bola Verbal adalah strategi yang digunakan untuk mendorong kerjasama kelompok atau tim. Dengan strategi ini siswa bisa melatih keterampilan mental dalam permainan yang penuh aksi dan tempo tinggi, serta strategi ini menumbuhkan kerjasama tim.

Penerapan strategi Sepak Bola Verbal ini membentuk siswa dalam dua kelompok. Pengelompokan yang dilakukan dalam strategi Sepak Bola Verbal ini adalah pengelompokan secara heterogen yang dibentuk berdasarkan tingkat kemampuan akademisnya. Setiap kelompok terdiri dari siswa yang memiliki kemampuan akademis tinggi, sedang dan rendah. Pengelompokkan secara heterogen mempunyai beberapa keunggulan. Menurut Lie (2002:42) beberapa keunggulannya adalah sebagai berikut:

1. Memberikan kesempatan saling mengajar dan saling mendukung.

2. Meningkatkan relasi dan interaksi antar ras, etnik dan gender.

3. Memudahkan pengelolaan kelas karena adanya satu orang dengan kemampuan akademis tinggi, guru mendapat satu asisten untuk setiap 3 orang. Ginnis (2008:186-187) mengemukakan langkah-langkah proses pembelajaran strategi Sepak Bola Verbal adalah sebagai berikut :

1. Jelaskan bahwa tujuan permainan adalah menguji pengetahuan dan pemahaman. Bagi kelas menjadi dua tim. Tiap tim memiliki seorang kapten.

2. Jelaskan bahwa keberhasilan dalam pertandingan akan bergantung pada latihan yang serius. Training menuntut tim melalui sebuah topik yang 
disediakan, memeriksa fakta dan pemahaman satu dengan yang lain dan mengingat dengan detail untuk menjawab pertanyaan dari guru.

3. Ketika periode latihan selesai, semua buku dan catatan harus disingkirkan, kapten dipanggil bersama, koin dilontarkan untuk mengetahui siapa yang memulai (kick-off) dan permainan dimulai.

4. Tim dengan kick-off akan menerima pertanyaan dari guru. Siapapun dapat menjawab dalam waktu 5 detik. Jika menjawab dengan benar, mereka mempertahankan kepemilikan bola. Pertanyaan lain diajukan oleh guru. Lagi, jika gabungan tiga pertanyaan benar (= tiga kali memegang bola), dan gol! Begitu seseorang telah menjawab sebuah pertanyaaan, dia tidak dapat menjawab lagi sampai semua orang lain telah mencoba. Ini tergantung pada pemainnya, dan terutama kapten, untuk memantau siapa yang sudah dan siapa yang belum ikut serta.

5. Jika seorang pemain menjawab dengan salah, itu berarti suatu tackle, dan bola pindah ke lawan. Jadi guru harus mengajukan pertanyaan pada mereka. Jika tidak seorang pun menjawab dalam lima detik, bola lepas. Jika lawan dapat menjawab dalam lima detik berikutnya, mereka memegang bola dan mulai menerima pertanyaan.

6. Pelanggaran terjadi bila siswa meneriakkan jawaban saat bukan gilirannya, menjawab ketika tidak berhak, dan terutama berdebat dengan wasit! Wasit diminta menggunakan kartu kuning atau merah.
7. Pemenangnya adalah tim dengan gol yang lebih banyak diakhir pelajaran.

Berdasarkan langkah-langkah yang dikemukakan di atas, maka penulis memodifikasinya sebagai berikut :

a. Guru membagi siswa dalam dua kelompok atau tim dengan kemampua akademis yang berbeda. Kemudian guru meminta siswa untuk duduk bersama anggota kelompoknya. Tiap kelompok memilih kapten kelompoknya.

b. Tim dibentuk dengan tujuan untuk dapat mencetak gol sebanyak-banyaknya dan setiap anggota tim bertanggung jawab untuk dapat menjawab pertanyaan dari guru. Sedangkan kapten berfungsi untuk mengatur anggota tim yang mempresentasikan jawabannya ke depan kelas dan kapten juga mencatat banyaknya gol yang diperoleh tim.

c. Guru memberikan pengantar tentang materi yang akan dipelajari.

d. Guru membagikan LKS yang berisikan ringkasan materi dan soal latihan.

e. Ketika pemahaman terhadap LKS selesai, kapten dipanggil bersama, koin dilontarkan untuk mengetahui siapa yang memulai (kick-off) dan permainan dimulai.

f. Tim yang mendapat giliran pertama mulai menjawab pertanyaan dari guru sesuai dengan LKS. Jika menjawab dengan benar tiga pertanyaan berturutturut maka bola gol dan mereka mempertahankan kepemilikan bola. Begitu seseorang telah menjawab sebuah pertanyaan, dia tidak dapat menjawab lagi hingga semua anggota tim telah 
mencoba. Ini tergantung pada pemainnya terutama kapten, untuk memantau siapa yang sudah dan siapa yang belum ikut serta.

g. Jika seorang pemain menjawab dengan salah, itu berarti tackle (merebut bola dari lawan), dan bola pindah ke tim lawan. Guru mengajukan pertanyaan yang tidak bisa dijawab oleh tim pertama kepada tim yang mendapatkan kepemilikan bola berikutnya. I Pelanggaran terjadi bila siswa meneriakkan jawaban saat bukan gilirannya menjawab. Guru diminta menggunakan kartu kuning apabila ada siswa yang melakukan pelanggaran. Jika satu orang siswa sudah mendapatkan tiga kali kartu kuning, maka pelanggaran yang keempat siswa tersebut diberi kartu merah dan tim kehilangan satu gol.

i. Kalau ada soal yang tidak bisa dijawab oleh setiap tim, maka disini tugas guru membahas bersama soal yang sulit tersebut.

j.Guru menghentikan jalannya permainan karena dibatasi oleh waktu. Dan setiap kelompok menyimpulkan pelajaran hari ini.

k. Tim yang mengumpulkan gol paling banyak dinyatakan sebagai pemenang dan diberi penghargaan.

1. Diakhir pelajaran setiap kapten tim mengumpulkan daftar nama-nama anggota tim yang menjawab pertanyaan dan banyak gol yang telah dicetak.

Berdasarkan langkah-langkah di atas, penulis dapat menyimpulkan keuntungan dari strategi Sepak Bola Verbal sebagai berikut: a. Kegiatan ini menyenangkan dan menambah variasi belajar mengajar.

b. Siswa hampir tidak mengetahui bahwa mereka sedang diuji.

c. Dapat meningkatkan kerja kelompok tiap tim dalam mengerjakan latihan.

d. Dapat melatih kemampuan berbicara dalam memberikan pendapat.

e. Setiap siswa mempunyai kesempatan untuk menjawab satu pertanyaan yang diberikan.

\section{Lembar Kerja Siswa (LKS)}

Menurut Trianto (2009:222) LKS adalah panduan siswa yang digunakan untuk melakukan kegiatan penyelidikan atau pemecahan masalah, jadi Lembar Kerja Siswa dapat berupa panduan untuk latihan pengembangan aspek kognitif maupun panduan untuk latihan semua aspek pembelajaran dalam bentuk panduan eksperimen atau demonstrasi. LKS hendaknya ditulis secara sederhana dan menggunakan kalimat yang mudah dipahami siswa. LKS memuat sekumpulan kegiatan mendasar yang harus dilakukan oleh siswa untuk memaksimalkan pemahaman dalam upaya pembentukan kemampuan dasar sesuai indicator pencapaian hasil belajar yang harus ditempuh. Trianto (2009:223) mengemukakan komponen-komponen dalam LKS meliputi :

a. Judul eksperimen

b. Teori singkat tentang materi

c. Alat dan bahan

d. Prosedur eksperimen

e. Data pengamatan serta pertanyaan dan kesimpulan untuk bahan diskusi. 
Untuk mencapai tujuan pengajaran maka guru perlu memperhatikan langkahlangkah penyusunan LKS, sebagaimana yang dikemukakan oleh Rosman dalam Puspita (2003:10) sabagai berikut :

a. Merumuskan tujuan pengajaran yang akan dicapai dengan menggunakan LKS.

b. Menyusun alat evaluasi yang akan digunakan untuk menguji keberhasilan dalam belajar.

c. Menyusun bahan pengajaran secara logis dan sistematis yang relevan dengan tujuan.

d. Melukis LKS berdasarkan urutan kegiatan yang akan dilakukan murid untuk mencapai tujuan.

e. Mencoba dan merevisi LKS yang akan dirancang.

Berdasarkan langkah-langkah diatas, struktur dalam penyusunan LKS

dapat kita lihat seperti berikut :

a. Judul satuan konsep, sub konsep dan petunjuk lain terhadap penjelasan materi.

b. Petunjuk proses penyelesaian LKS dan pemberian materi singkat.

c. Adanya tugas atau latihan.

\section{METODOLOGI PENELITIAN}

Jenis penelitian ini adalah penelitian eksperimen, dengan rancangan penelitian Randomized Control Group Only Design. Populasi dalam penelitian ini adalah seluruh siswa kelas VIII MTsN Padang Sibusuk Kabupaten Sijunjung. Teknik pengambilan sampel dengan Purposive Sampling, diperoleh kelas sampel adalah kelas VIII2 kelas eksperimen dan VIII1 kelas kontrol.
Instrumen yang digunakan adalah tes akhir hasil belajar dan analisis data dilakukan dengan uji t.

\section{HASIL DAN PEMBAHASAN}

Berdasarkan hasil analisis jawaban siswa pada kegiatan tes akhir diperoleh data nilai hasil belajar siswa yang dapat dilihat pada tabel berikut.

\begin{tabular}{|r|r|r|r|r|r|r|}
\hline Tabel 2. Nilai Rata-rata. Simpangan Baku dan Variansi Kedua Kelas Sampel. \\
\hline Kelas & $\mathrm{N}$ & $\mathrm{X}$ & $\mathrm{S}$ & $\mathrm{s}^{2}$ & tritua & trabu \\
\hline Eksperimen & 22 & 70,90 & 11,18 & 125,03905 & 2,88 & 1,68 \\
\hline Kontrol & 22 & 60,18 & 13,49 & 181,87013 & & \\
\hline
\end{tabular}

Dari hasil penelitian yang dilakukan diketahui bahwa hasil belajar biologi siswa kelas eksperimen lebih baik dari pada kelas kontrol. Ini menunjukkan bahwa penerapan strategi Sepak Bola Verbal disertai LKS dapat meningkatkan hasil belajar biologi siswa. Hal ini dapat dilihat dari rata-rata tes akhir yang diikuti oleh kedua kelas sampel, dimana rata-rata nilai kelas eksperimen lebih baik dari nilai rata-rata kelas kontrol. Selain itu dapat dilihat dari jumlah siswa yang tuntas dan tidak tuntas. Pada kelas eksperimen siswa yang tuntas 18 orang sedangkan kelas kontrol siswa yang tuntas 10 orang.

Berdasarkan pengamatan penulis selama penelitian, terlihat siswa pada kelas eksperimen yang menggunakan strategi Sepak Bola Verbal disertai LKS lebih bersemangat dalam belajar. Ini disebabkan adanya kesadaran anggota tim untuk mempertahankan timnya. Kemudian timbulnya rasa tanggung 
jawab dan kerjasama tim dalam melakukan diskusi LKS sehingga tim termotivasi untuk merebut bola agar mendapatkan gol sebanyak-banyaknya. Akibatnya siswa menjadi lebih bersemangat dalam kegiatan ini. Hal ini sesuai dengan pendapat Trianto (2009:223) dengan adanya LKS dapat memaksimalkan pemahaman siswa dalam upaya pembentukan kemampuan dasar sesuai indikator pencapaian hasil belajar. Dengan adanya LKS dapat melatih kerjasama tim dalam kelompok dan dapat saling berbagi pendapat. Pada saat perlombaan tim, guru membimbing langsung kegiatan siswa. Dalam kegiatan pelemparan bola, tim yang mendapat giliran menjawab pertanyaan akan merasa senang dan bersemangat. Strategi Sepak Bola Verbal dapat meningkatkan belajar siswa karena dapat menerapkan permainan dalam proses pembelajaran.

Permainan dalam strategi Sepak Bola Verbal bisa dijadikan sebagai latihan yang menyenangkan untuk memancing pendapat atau keterampilan siswa dan bisa dijadikan landasan yang dapat mendorong siswa untuk berpartisipasi dalam pembelajaran. Sesuai yang diungkapkan oleh Ginnis (2008:187) bahwa strategi Sepak Bola Verbal merupakan strategi pembelajaran yang menyenangkan dan menambah variasi aktivitas. Tim akan lebih bersemangat lagi apabila tim dapat mencetak gol dan mendapatkan tepuk tangan yang meriah dari anggota tim sehingga tim terus berusaha untuk mempertahankan kepemilikan bola. Sedangkan tim dari kelompok lain akan merasa kecewa apabila belum mendapat giliran menjawab. Tim merasa bosan karena harus menunggu tim lawan yang belum juga kalah. Diakhir pertemuan kapten tim memberikan laporan banyak gol yang telah diperoleh kepada guru (Lampiran 17). Tim yang mencetak gol paling banyak akan mendapat penghargaan dari guru. Pada kelas kontrol proses pembelajaran menggunakan metode ceramah dan tanya jawab yang disertai dengan LKS. Guru menjelaskan materi dalam bentuk ceramah dan setelah menjelaskan materi guru membagikan LKS kepada setiap siswa. LKS yang diberikan dikerjakan secara individu. Dalam mengerjakan LKS, siswa diharapkan bisa mempelajari dan menemukan sendiri bagaimana memperoleh suatu pengetahuan. Pada kelas kontrol masih banyak siswa yang kurang aktif dalam belajar dan mendapatkan hasil belajar yang masih rendah, hal ini disebabkan karena siswa masih terfokus pada penjelasan guru. Belajar aktif menuntut siswa untuk bersemangat, menyenangkan dan penuh gairah sehingga siswa merasa leluasa dalam berfikir dan beraktivitas. Hal ini sesuai dengan yang diungkapkan oleh Sumadi (2004:71) yang menyatakan bahwa keaktifan siswa dapat dilihat dari belajar dalam kelompok dan mengkomunikasikan hasil pikiran, penemuan dan penghayatan nilai-nilai secara lisan. Dari uraian di atas maka dapat disimpulkan bahwa pembelajaran dengan menggunakan strategi Sepak Bola Verbal yang disertai dengan LKS memberikan pengaruh yang berarti terhadap hasil belajar siswa. Dengan demikian pembelajaran dengan menggunakan strategi Sepak Bola 
Verbal telah dibuktikan secara statistik dapat menjawab permasalahan dalam penelitian ini, sehingga hipotesis (H1) diterima.

\section{KESIMPULAN}

Berdasarkan hasil analisis data dan pembahasan yang dikemukakan dapat disimpulkan bahwa penerapan strategi Sepak Bola Verbal disertai LKS dapat meningkatkan hasil belajar biologi siswa kelas VIII MTsN Padang Sibusuk Kabupaten Sijunjung.

\section{DAFTAR KEPUSTAKAAN}

Arikunto, Suharsimi. 2006. Prosedur Penelitian Suatu Pendekatan Praktik. Jakarta : Rineka Cipta.

-----------.. 2010. Dasar-dasar Evaluasi Pendidikan. Jakarta: Bumi Aksara.

Ginnis, Paul. 2008. Trik dan Taktik Mengajar Strategi Meningkatkan Pencapaian Pengajaran di Kelas. Jakarta : Indeks.

Lie, Anita. 2002. Cooperatif Learning. Jakarta : Grasindo.

Sagala, Syaiful. 2010. Konsep Dan Makna Pembelajaran Untuk Membantu Memecahkan Problematika Belajar Dan Mengajar. Bandung: Alfabeta.

Silberman, Melvin L. 2006. Active Learning 101 Cara Belajar Siswa Aktif. Bandung: Nusamedia.

Sudjana. 2005. Metode Statistika. Bandung: Tarsito.

Slameto. 2003. Belajar dan Faktor-faktor yang mempengaruhinya. Jakarta: Rineka Cipta.
Suryabrata, Sumadi. 2010. Metodologi Penelitian. Jakarta: Raja Gravindo Persada.

Trianto. 2009. Mendesain Model Pembelajaran Inovatif-Progresif: Konsep, Landasan, dan Implementasinya pada Kurikulum Tingkat Satuan Pendidikan (KTSP). Jakarta : Kencana Prenada Media.

Tim Penulis. 2009. Pedoman Penulisan Skripsi Program Studi Pendidikan Biologi. Padang: STKIP-PGRI Sumbar. 